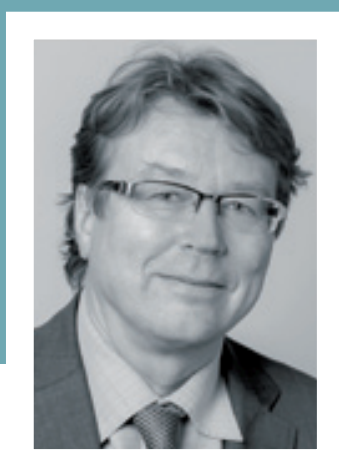

\title{
PÄ̈̈KIRJOITUS
}

\section{HelpPo Ja halpa haAstattelu}

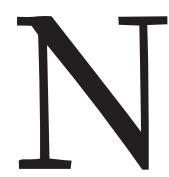

OPEA KATSELMUS AIKUISKASVATUSLEHDEN vuosikertoihin 2000-luvulta paljastaa jotain olennaista alan tutkimustoiminnasta ja metodologiasta. Aikuiskasvatuksen ilmiökenttä hahmotetaan luonteeltaan sellaisena, josta sopii hankkia tietoa menemällä ihmisten luokse ja haastattelemalla heitä. Tarkoitus määrittää olennaisesti saadun aineiston luonnetta. Tarkoituksesta riippumatta haastattelijan ja haastateltavan välinen yhteisymmärrys ja keskinäinen luottamus lopulta ratkaisevat, syntyykö haastattelumateriaalista aineisto, jonka perusteella tutkija voi tehdä luotettavia tulkintoja tutkimastaan ilmiöstä.

Liian harvoin tutkimusartikkeleissakin reflektoidaan riittävän huolellisesti haastattelijan ja haastateltavan keskinäistä suhdetta ja luottamuksen astetta, osapuolten välistä sosiaalista ja kulttuurista välimatkaa, haastattelijan ominaisuuksien vaikutusta haasteltavan puhetapaan tai vuorovaikutustilanteen valtaulottuvuutta. Haastattelijan olisi aina terveellistä pohtia, millainen haastattelusta olisi tullut, jos hän olisi ollut toista sukupuolta, eri-ikäinen, kuulunut toiseen etniseen ryhmään ja yhteiskuntaluokkaan.

VALTASUHTEET TUTKIMUSHAASTATTELUSSA -artikkelissaan Sonja Kosunen ja Jaakko Kauko
(Politiikka 1/2016) tekevät omien tutkimuskokemustensa varassa mielenkiintoisia huomiota haastattelutilanteen valta-asetelmasta. Yleensä tutkijalla on ajateltu olevan valtaa suhteessa haastateltavaan kysymyksenasettelun, aseman ja asiantuntijuuden perusteella. Haastattelija on tilanteessa toimija, jonka intressin vuoksi haastateltava ylipäätään saa puheenvuoron.

Kosusen ja Kaukon mukaan haastattelijan ja haastateltavan välinen valtasuhde vaikuttavaa olennaisesti siihen, millainen aineisto haastattelusta lopulta syntyy. Valtasuhde on niin olennainen osa prosessia, että se aktivoituu jo ennen varsinaista haastattelutilannetta. Haastateltavan ja haastattelijan suhteesta ja sen perustana olevasta valtahierarkiasta käydään jatkuvaa neuvottelua.

Vaitöstutkimusta Families and the Social Space of School Choice in Urban Finland (Helsingin yliopisto 2016) varten peruskoululaisten vanhempia kouluvalinnoista haastatellessaan Kosunen pani merkille, että muotoutuvaan aineistoon ei vaikuta pelkästään haastattelijan ikä tai sukupuoli. Kun haastattelun aiheena ovat kouluikäiset lapset ja heidän koulutustaan koskevat valinnat, vaikuttavaksi tekijäksi voi paljastua myös se, onko haastattelijalla itsellään saman ikäisiä lapsia. Lapsettomalle haastattelijalle 
OLENNAISESTI SIIHEN, MILLAISIA SIGNAALEJA

\author{
TUTKITTAVA KOHDE HÄNELLE LÄHETT ̈̈̈.
}

haastateltavat tulevat selventäneeksi sellaisia itsestään selvinä pitämiään tekijöitä ja uskomuksia, joita he eivät ottaisi puheeksi "vertaisensa" kanssa.

NIIN TÄHÄN LEHTEEN tarjotuissa artikkeleissa kuin kasvatustieteissä tehdyissä pro gradu -tutkielmissa on usein aineistona $10-15$ ihmisen, noin tunnin kestäneet haastattelut. Harvemmin tutkimuksen tekijä kuitenkaan kriittisesti reflektoi aineiston tuottamisen ehtoja ja sitä, mitä haastateltujen tuottama puhe edustaa. Millaista aineistoa syntyy siitä, että kaksi toisilleen vierasta ihmistä tapaavat yhden kerran tunnin ajan ja toinen pyytää tutkijan arvovallalla toista puhumaan annetusta aiheesta? Tämä kysymys nousee väistämättä mieleen lukiessa etnografisen tutkimuksen tekijöiden kenttätyössä saatuja kokemuksia. Jeremy Gouldin ja Katja Uusihakalan toimittamassa teoksessa Tutkija peilin edessä (Gaudeamus 2016) on runsaasti kuvauksia vuorovaikutukselle rakentuvan aineistonhankinnan vaikeuksista. Tutkittavan ihmisen näkökulman ymmärtäminen edellyttää läsnäoloa, osallistumista ja vuorovaikutusta. Aluksi kenttätyön tekijät usein tekevät aivan vääriä tulkintoja haastatellessaan tutkimuskohteitaan. Vasta vähitellen he alkavat ymmärtää tutkittaviensa ajattelua, toimintaa ja valintoja sekä niiden perusteluja. Kunnon aineiston hankkiminen edellyttää tutkijan position ja osapuolten vuorovaikutussuhteen kriittistä reflektointia.

Haastattelija ei ole koskaan "yleisihminen" tekemässä haastattelua jossakin "yleisessä paikassa".
Gould havainnollistaa tätä analogian kautta (s. 26): "Vertauskuvallisesti sanottuna kutakin tutkijaa on omien erityispiirteiden ja henkilöhistorian kautta eri tavalla viritelty (kalibroitu) ottamaan vastaan ja käsittelemään määrätynlaisia aistihavaintoja. Avaruustutkimuksessa käytetyt luotaimet on kalibroitu rekisteröimään vain tiettyjä valoaaltoja tai törmäyksiä vain tietynlaisiin partikkeleihin. Vastaavasti tutkijan kognitiivinen apparaatti on rodun, sukupuolen, iän ja luokka-aseman mutta ennen kaikkea kulttuurin, kasvatuksen ja omien kokemusten perusteella luonnostaan viritelty huomioimaan (tai olemaan huomioimatta) tietynlaisia signaaleja." Eikä aineiston tuottamista rajoita vain tutkijan kognitiivinen apparaatti: tutkijan ominaisuudet vaikuttavat olennaisesti siihen, millaisia signaaleja tutkittava kohde hänelle lähettää.

HAASTATTELUA AINEISTONKERUUN MENETELMÄNÄ käytetään turhankin rutiininomaisesti - pohtimatta huolellisesti, mihin tarkoitukseen saatua aineistoa voi käyttää. Ei ole harvinaista saada luettavaksi artikkelikäsikirjoitus, jossa tutkimusta varten tehdyt haastattelut eivät lisää ymmärrystä tutkittavasta ilmiöstä. Lehden toimituskunta joutuu silloin kysymään, olisiko artikkeli voitu kirjoittaa ilman käytettyä haastatteluaineistoa. Se kertoo ennen muuta haastattelumenetelmän pinnallisesta käytöstä. Haastattelemalla ei automaattisesti synny tutkimustarkoituksiin soveltuvaa aineistoa.

Heikki Silvennoinen 